\title{
Tumor-suppressing roles of miR-214 and miR-218 in breast cancer
}

\author{
BO LIU, YANFENG TIAN, FANG LI, ZENGREN ZHAO, XIA JIANG, \\ CONGJIE ZHAI, XIAODONG HAN and LIKE ZHANG
}

\begin{abstract}
Department of General Surgery, The First Hospital of Hebei Medical University, Shijiazhuang, Hebei 050031, P.R. China
\end{abstract}
Received November 26, 2015; Accepted January 13, 2016

DOI: $10.3892 /$ or.2016.4749

\begin{abstract}
MicroRNAs (miRNAs) are small non-coding RNAs that are key post-transcriptional regulators of gene expression. MicroRNA-214 (miR-214) and microRNA-218 (miR-218) have shown the function of tumor suppressors in various types of human cancers. However, the biological functions of miR-214 and miR-218 in breast cancer have not been elucidated completely. The present study evaluated the expression and biological function of miR-214 and miR-218 in human breast cancer. Our results revealed that the expression of miR-214 and miR-218 were significantly decreased in breast cancer tissues compared with adjacent tissues. The aberrant expression of miR-214 and miR-218 were negatively associated with $\mathrm{Ki}-67$, and the miR-218 expression was positively associated with progesterone receptor (PR) in breast cancer tissues. In vitro, the cell proliferation and migration were decreased, cell apoptosis was induced, and cell cycle was also disturbed in miR-214 or miR-218 overexpressed breast cancer cells. Our results demonstrated that miR-214 and miR-218 function as tumor suppressors in breast cancer, and may become biomarkers and potential therapeutic targets in breast cancer.
\end{abstract}

\section{Introduction}

Breast cancer is one of the most common malignancies among females (1), which can occur in humans and other mammals, and most cases are women (2). Over 1 million persons are diagnosed with breast cancer each year (3). Similarly to other cancers, carcinogenesis of breast cancer is a complex process. Although mortality rate of breast cancer has been observably reduced, metastatic breast cancer still remains puzzling (4). The mechanisms of carcinogenesis and metastasis need to be better clarified.

MicroRNA (miRNA) is a class endogenous non-coding single-stranded RNA. As circulating marker, miRNA is being

Correspondence to: Professor Yanfeng Tian, Department of General Surgery, The First Hospital of Hebei Medical University, Donggang Road No. 89, Shijiazhuang, Hebei 050031, P.R. China E-mail: tianyanfeng1212@163.com

Key words: breast cancer, microRNA, miR-214, miR-218, cell proliferation, cell apoptosis, cell cycle, cell migration studied extensively $(5,6)$. miRNAs are able to downregulate approximately $1 / 3$ human genes by binding to 3 '-untranslated region (3'-UTR) of target mRNA $(5,7)$. miRNAs are involved in many biological processes, such as cell proliferation, apoptosis, migration and carcinogenesis (8-11). Many miRNAs are also involved in carcinogenesis and development of breast cancer $(9,10)$. It has been shown that miR-200c, miR-206, miR-335, miR-494 and miR-125b are downregulated in breast cancer tissues, suggesting that they may play tumor suppressor roles (12-16). As oncogenes of breast cancer, miR-155, miR-21, miR-210, miR-373 and miR-10b are upregulated in patients with breast cancer (17-20). The miR-214 is decreased in breast cancer (21), and miR-218 is also known as a tumor suppressor in prostate cancer, hepatocellular carcinoma and glioblastoma (22-24), but the mechanisms of both miR-214 and miR-218 are unclear.

In the present study, we investigate the expression of miR-214 and miR-218 in breast cancer and adjacent tissues, and analyzed the correlations in miR-214 and miR-218 expression and the clinicopathological characteristics. The effects of miR-214 or miR-218 on cell proliferation, apoptosis and cell cycle were also determined in vitro. Our results may provide new biomarkers for diagnosis, prognosis and therapy, and be helpful to clarify the mechanisms of post-transcription regulation in breast cancer.

\section{Materials and methods}

Clinical samples. Forty-nine breast cancer tissues and their paired adjacent tissue samples, which were diagnosed by pathological surgical resection, were collected between 2013 and 2015 at The First Hospital of Hebei Medical University (Shijiazhuang, China). The tissues were frozen in liquid nitrogen at $-80^{\circ} \mathrm{C}$ immediately until use. Breast cancer patients who had undergone chemotherapy or radiation therapy before surgery were excluded.

Ethics statements. Permission to use human tissue samples for research purposes was approved by the Biomedical Ethics Committee of Hebei Medical University, Shijiazhuang, Hebei, China. All patients were female and consented to participate in the present study.

Cell line and transfection. Breast cancer cell line MCF-7 was obtained from the American Type Culture Collection (ATCC; Manassas, VA, USA), cultured in RPMI-1640 containing 
$10 \%$ fetal bovine serum (FBS), $100 \mathrm{U} / \mathrm{ml}$ of penicillin, and $100 \mathrm{mg} / \mathrm{ml}$ of streptomycin (Gibco, Grand Island, NY, USA) in a humidified atmosphere containing $5 \% \mathrm{CO}_{2}$ at $37^{\circ} \mathrm{C}$. For transfection, cells were seeded and cultured for $24 \mathrm{~h}$ in 12 -well plates. According to the manufacturer's instructions, cells were transfected with miR-214 mimic, miR-218 mimic or negative control, respectively, by Lipofectamine 2000 (Invitrogen Life Technologies, Grand Island, NY, USA) in serum-free medium. Six hours after the transfection, the complete medium was changed and maintained for $48 \mathrm{~h}$ at $37^{\circ} \mathrm{C}$ in $5 \% \mathrm{CO}_{2}$. The mimics of miR-214, miR-218 and negative control were purchased from Guangzhou RiboBio Co., Ltd. (Guangzhou, China).

Real-time reverse transcription polymerase chain reaction (real-time RT-PCR). Total RNA was extracted from breast cancer tissues, adjacent tissues and MCF-7 cells by TRIzol reagent (Invitrogen), according to the manufacturer's instructions. Reverse transcription PCR and real-time PCR were performed with TaqMan microRNA Reverse Transcription kit and TaqMan Universal Master Mix (Applied Biosystems, Foster City, CA, USA, respectively) following standard protocol. U6 was used as an endogenous control to normalize variance. The primers of miR-214, miR-218 and U6 were purchased from Applied Biosystems. The fold changes were calculated via relative quantification $\left(2^{-\triangle C T}\right)$.

Cell proliferation assay. Cell proliferation was determined by the Cell Counting kit-8 assay (CCK-8; Dojindo Molecular Technologies, Inc., Beijing, China). MCF-7 cells (1,000 cells/well) were cultured in 96-well plates. After incubation, $10 \mu l$ of the CCK- 8 solution was added to each well of the plate, and incubated for $1 \mathrm{~h}$ in the incubator, and the absorbance was measured at $450 \mathrm{~nm}$ using a microplate reader according to the CCK-8 kit manufacturer's instructions.

Flow cytometry. The effects of miR-214 and miR-218 on breast cancer cell apoptosis and cell cycle were examined by flow cytometry (BD Biosciences, Mansfield, MA, USA). In brief, MCF-7 cells were transfected with miR-214 mimic, miR-218 mimic or negative control for $48 \mathrm{~h}$, the cells were completely collected including apoptotic cells in culture medium, and washed twice with cold PBS. The cell apoptosis were analyzed by Annexin V-FITC detection kit ( Neobioscience Technology, Shenzhen, China) according to the manufacturer's protocol. For determining the cell cycle, the cells were transfected for $48 \mathrm{~h}$, washed twice with PBS, treated with trypsin, and fixed with $75 \%$ ethanol overnight at $-20^{\circ} \mathrm{C}$, and incubated with $100 \mathrm{mg} / \mathrm{ml} \mathrm{RNase}$ A and $50 \mathrm{mg} / \mathrm{ml}$ propidium iodide (PI) at room temperature for $30 \mathrm{~min}$. The percentage of the G0/G1, S and $\mathrm{G} 2 / \mathrm{M}$ populations were evaluated in each group. The data were analyzed by CellQuest Pro software. Each experiment was performed in triplicate.

Wound-healing assay. MCF-7 cells were grown to confluence. A wound was made by scraping with a conventional pipette tip across the confluence cell layer, and washed with PBS twice. Forty-eight hours after scraping, migration was determined, using the ImageJ, as a percentage of healing area relative to the initial wound area.
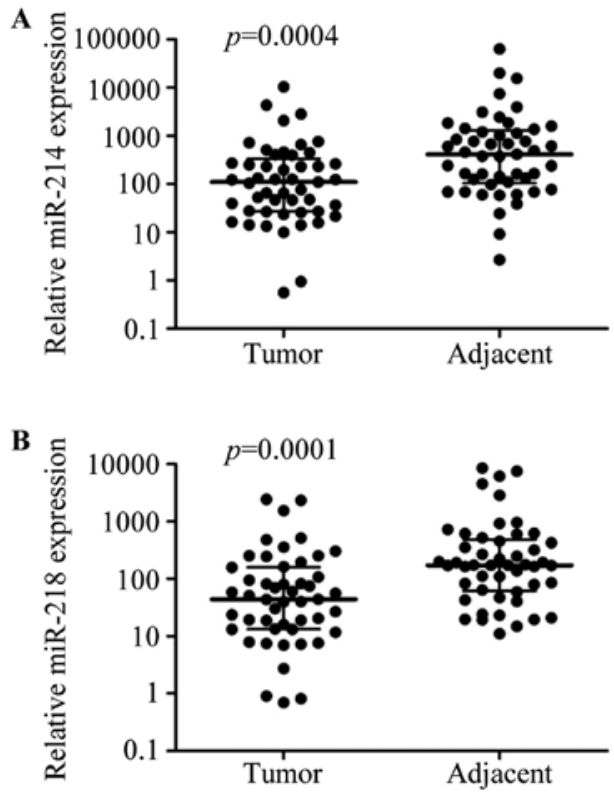

Figure 1. The expression of miR-214 and miR-218 were decreased in breast cancer tissues. The (A) expression of miR-214 and (B) miR-218 was detected in breast cancer tissues and adjacent tissues of 49 patients by real-time RT PCR. The P-values were assessed by non-parametric test.

Statistical analysis. Data were processed by the SPSS Graduate Pack 13.0, GraphPad 5 software or the Student's t-test. P $<0.05$ was considered to be statistically significant.

\section{Results}

miR-214 and miR-218 are downregulated in breast cancer tissues. To assess the effects of miR-214 and miR-218 on breast cancer development, we first evaluated miR-214 and miR-218 expression levels in breast cancer and adjacent cancer tissues by real-time RT-PCR. The expression of miR-214 and miR-218 was significantly downregulated in breast cancer tissues compared with matching adjacent tissues $(\mathrm{P}<0.01$, respectively; Fig. 1).

Correlation of miR-214 or miR-218 expression with clinicopathological data. We further evaluated the correlation of miR-214 or miR-218 expression and the clinicopathological factors, including age, tumor size, lymph node metastasis, clinical stage, estrogen receptor (ER), progesterone receptor (PR), epidermal factor receptor-2 (HER-2), p53 and Ki-67. ER, PR, HER-2, p53 and Ki-67 were detected by immunohistochemistry, respectively. When the number of stained cells was $>10 \%$ in one field, it was defined as positive. We found that miR-214 and miR-218 expression was negatively associated with Ki-67 expression (Fig. 2A and C; P=0.025, 0.018, respectively), and the expression of $\mathrm{PR}$ was positively associated with miR-218 (Fig. 2D; $\mathrm{P}=0.027$ ), but not miR-214 (Fig. 2B; $\mathrm{P}=0.4$ ). There was no correlation between the miR-214 or miR-218 expression level with age, tumor size, lymph node metastasis, stage, ER, HER-2 and p53 (Table I).

Overexpression of $m i R-214$ and $m i R-218$ inhibits the breast cancer cell proliferation. To test the biological function of miR-214 and miR-218, the miR-214 mimic, miR-218 mimic and 

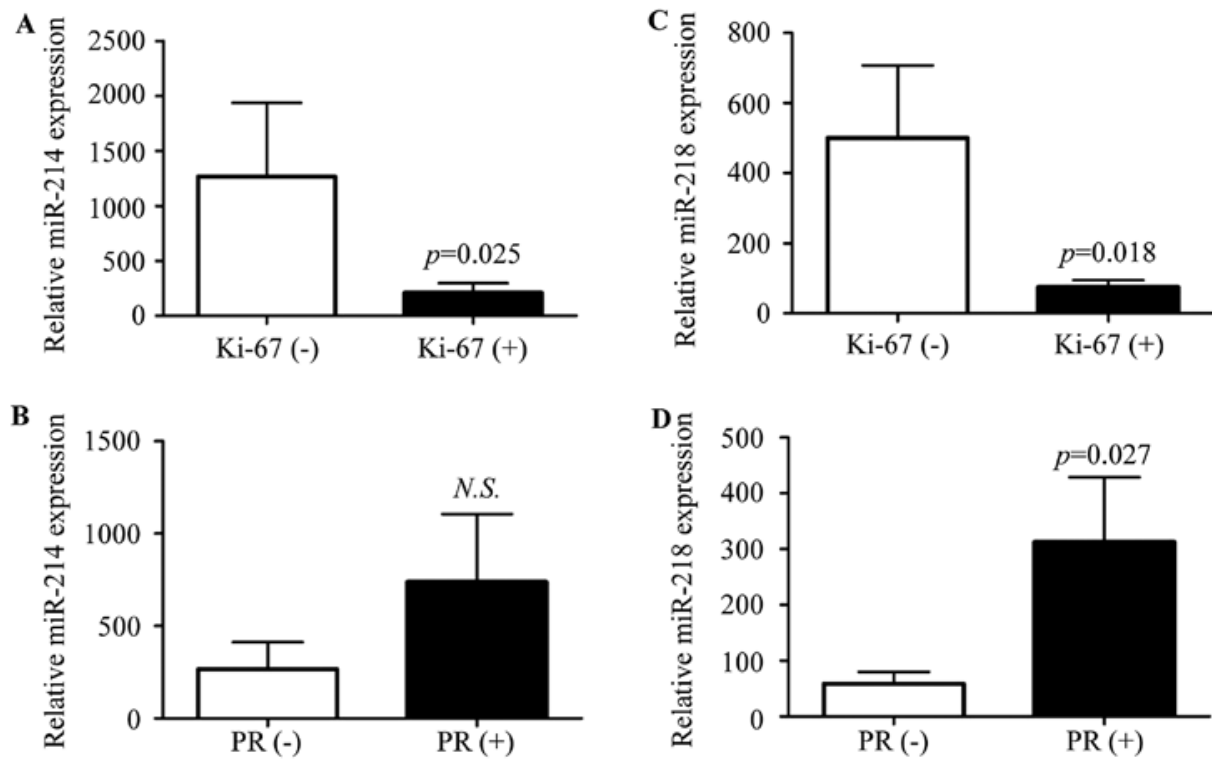

Figure 2. Correlation analysis of miR-214 and miR-218, respectively, and clinicopathological data. The correlation between (A and B) miR-214 or (C and D) miR-218 expression and Ki-67 or progesterone receptor (PR) were evaluated, respectively. Ki-67 and PR were detected by immunohistochemistry, when the number of stained cells was $>10 \%$ in one field, it was defined as positive. The P-values were assessed by non-parametric test. NS, indicates no statistical difference.

Table I. Correlations of miR-214 and miR-218 expression and the clinicopathological characteristics of breast cancer patients.

\begin{tabular}{|c|c|c|c|c|c|}
\hline Parameters & $\begin{array}{l}\text { No. of } \\
\text { patients }\end{array}$ & $\begin{array}{l}\text { Relative miR-214 expression } \\
\text { Median (interquartile range) }\end{array}$ & P-value & $\begin{array}{l}\text { Relative miR-218 expression } \\
\text { Median (interquartile range) }\end{array}$ & P-value \\
\hline Age (years) & & & 0.27 & & 0.81 \\
\hline$\leq 52$ & 25 & $104.02(26.96-689.51)$ & & $43.73(10.42-179.10)$ & \\
\hline$>52$ & 24 & $116.64(26.30-221.89)$ & & $47.39(13.84-144.50)$ & \\
\hline Tumor size $(\mathrm{cm})$ & & & 0.82 & & 0.63 \\
\hline$\leq 2$ & 17 & $122.86(25.15-427.12)$ & & $30.29(5.10-248.76)$ & \\
\hline$>2$ & 32 & $107.23(29.92-246.91)$ & & $47.38(18.90-100.79)$ & \\
\hline Lymph node metastasis & & & 0.90 & & 0.94 \\
\hline Negative & 23 & $110.43(26.69-406.72)$ & & $50.74(15.88-94.53)$ & \\
\hline Positive & 26 & $94.33(26.87-294.63)$ & & $43.88(12.79-170.83)$ & \\
\hline Clinical stage $^{a}$ & & & 0.77 & & 0.72 \\
\hline I & 11 & $124.65(23.62-447.52)$ & & $81.16(7.47-303.16)$ & \\
\hline II, III & 38 & $107.23(27.63-253.54)$ & & $43.88(15.25-119.50)$ & \\
\hline ER & & & 0.77 & & 0.32 \\
\hline Negative & 13 & $122.86(37.19-160.50)$ & & $26.69(10.39-160.97)$ & \\
\hline Positive & 36 & $90.27(26.04-437.32)$ & & $57.13(18.77-161.17)$ & \\
\hline Her-2 & & & 0.82 & & 0.68 \\
\hline Negative & 20 & $65.41(17.21-698.63)$ & & $35.18(9.21-161.17)$ & \\
\hline Positive & 29 & $123.76(38.05-255.90)$ & & $50.74(16.05-163.83)$ & \\
\hline p53 & & & 0.29 & & 0.16 \\
\hline Negative & 33 & $65.81(22.50-333.40)$ & & $40.06(9.82-132.00)$ & \\
\hline Positive & 16 & $124.21(48.80-398.44)$ & & $58.11(24.42-329.89)$ & \\
\hline
\end{tabular}

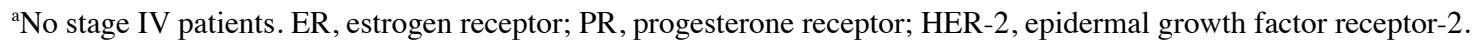

negative controls were purchase from Applied Biosystems. The overexpression of miR-214 or miR-218 was carried out in
MCF-7 cells by transfection with miR-214 mimic or miR-218 mimic, respectively. The expression of miR-214 (Fig. 3A) 

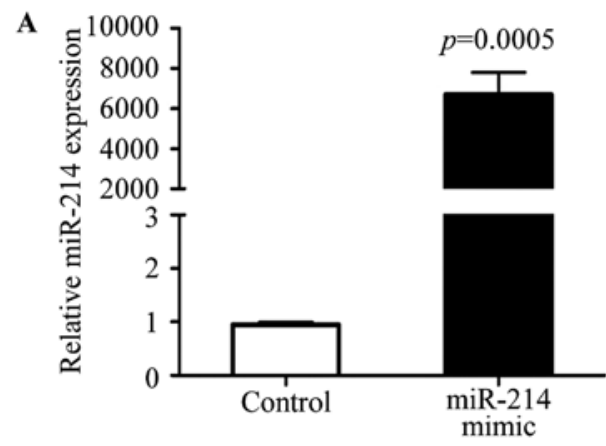

B

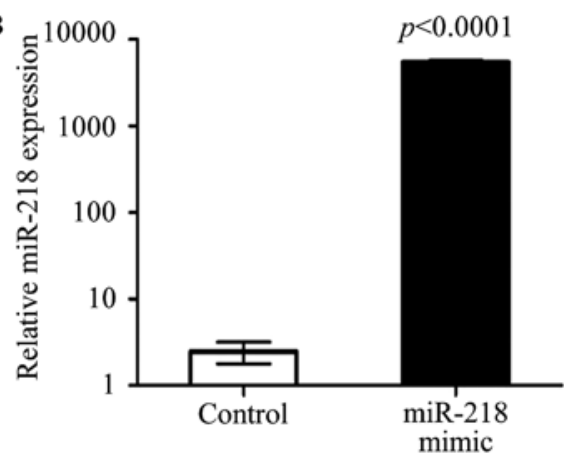

C

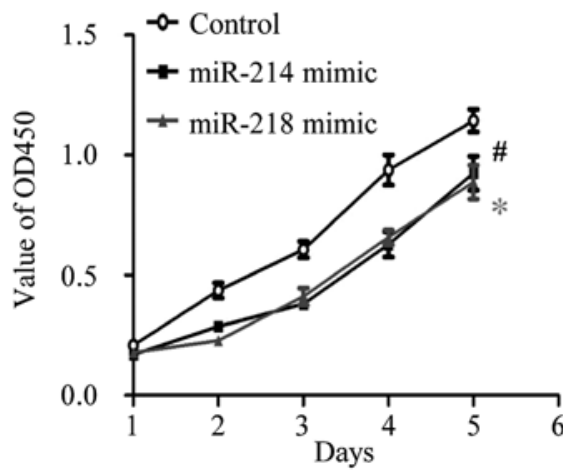

Figure 3. Overexpression of miR-214 and miR-218 inhibits breast cancer cell proliferation. (A) expression of miR-214 and (B) miR-218 was upregulated with the transfection of miR-214 mimic or miR-218 mimic in MCF-7 cells, respectively. (C) Forty-eight hours after transfection, the cell proliferation was determined by CCK- 8 assay. The experiments were performed in triplicate. ${ }^{~} \mathrm{P}=0.0253$ (miR-214 mimic transfected cells vs. negative control cells). ${ }^{*} \mathrm{P}=0.0282$ (miR-218 mimic transfected cells vs. negative control cells).

and miR-218 (Fig. 3B) were detected by real-time RT PCR in transfected cells. To investigate the effect of miR-214 and miR-218 on cell proliferation, cell proliferation assay were performed by the Cell Counting kit-8 (CCK-8; Dojindo Molecular Technologies), according to the manufacturer's instructions. After transfection with miR-214 and miR-218 mimic, respectively, the cells proliferation was significantly reduced compared to negative control transfected MCF-7 cells (Fig. 3C). The data showed that miR-214 and miR-218 were able to regulate cell proliferation of breast cancer.

Overexpression of miR-214 and miR-218 perturbs breast cancer cell cycle. The cell cycles were analyzed by flow cytometry (BD Biosciences) after staining with propidium iodide (PI). The percentage of cells in the G0/G1, S and G2/M phases was, respectively, evaluated under the negative control (Fig. 4A), miR-214 (Fig. 4B) or miR-218 (Fig. 4C) mimic transfection. As shown in Fig. 4D, the percentage of $\mathrm{S}$ phase cells
$\mathbf{A}$

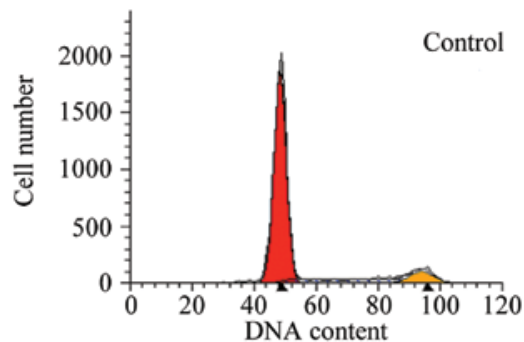

B

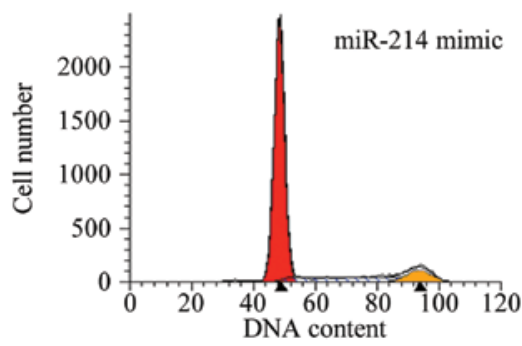

C
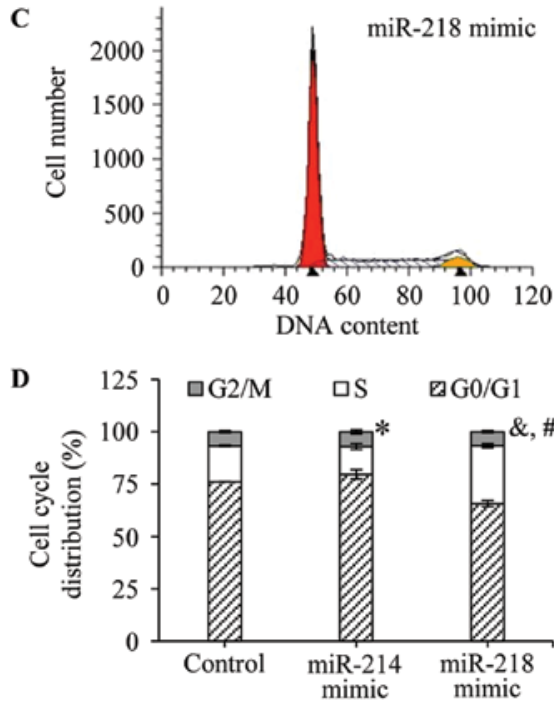

Figure 4. Effects of miR-214 and miR-218 on the cell cycle of breast cancer After transfection, the cells were washed with PBS twice, and treated with trypsin. The surviving cells were collected, excepting apoptotic cells, in culture medium. The cell cycles were analyzed by flow cytometry after staining with PI. The representative results of cell cycles are shown in (A) negative control, (B) miR-214 mimic and (C) miR-218 mimic transfected cells. (D) In addition, the percentage of cells in the G0/G1, S and G2/M phases was, respectively, evaluated. The experiments were performed in triplicate. ${ }^{*} \mathrm{P}=0.0298$ (the percentage of $\mathrm{S}$ phase cells, miR-214 mimic transfected cells vs. negative control cells). ${ }^{\circledR} \mathrm{P}=0.0009$ (the percentage of $\mathrm{S}$ phase cells, miR-218 mimic transfected cells vs. negative control cells). ${ }^{\#} \mathrm{P}=0.006$ (the percentage of G0/G1 phase cells, miR-218 mimic transfected cells vs. negative control cells).

was significantly decreased in miR-214 overexpressed MCF-7 cells comparing with control cells $(13.21 \pm 1.38$ vs. 17.20 \pm 0.39 , $\mathrm{P}=0.0298)$, accompanied by an increase of $\mathrm{G} 0 / \mathrm{G} 1$ phase cell ratio $(79.78 \pm 2.29$ vs. $76.08 \pm 0.02, \mathrm{P}=0.11$, no-statistical significance). The percentage of $\mathrm{G} 0 / \mathrm{G} 1$ phase cells was significantly reduced in miR-218 overexpressed MCF-7 cells compared with control cells $(65.74 \pm 1.40$ vs. $76.08 \pm 0.02, \mathrm{P}=0.006$; Fig. 4D), and a marked increase of the cell ratio of $S$ phase was observed in the miR-218 mimic transfected cells, compared to control cells $(27.62 \pm 0.98$ vs. $17.20 \pm 0.39, P=0.0009$; Fig. 4D). The results confirmed that miR-214 and miR-218 disturbed the breast cancer cell cycle. 
$\mathbf{A}$

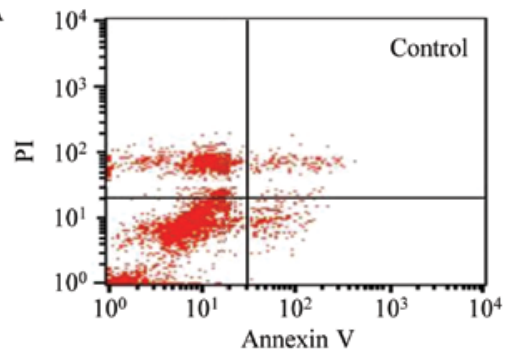

B

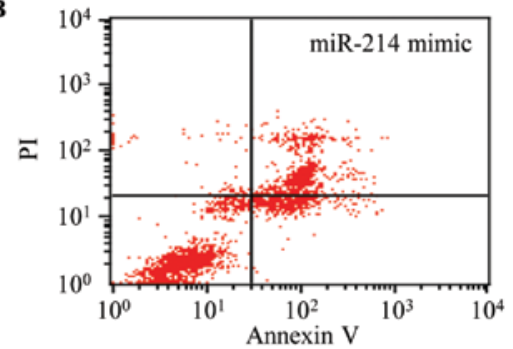

C
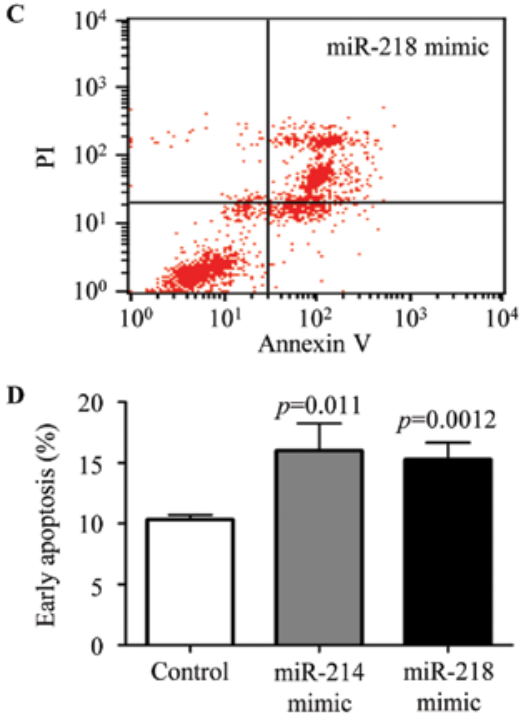

Figure 5. Effects of miR-214 and miR-218 on apoptosis of breast cancer cells. After (A) negative control, (B) miR-214 mimic and (C) miR218 mimic transfection, the cells were collected including apoptotic cells in culture medium. In addition, cell apoptosis was analyzed by Annexin V-FITC detection kit. (A-C) Representative results are shown (D) The percentage of early apoptotic cells was calculated, respectively. The experiments were performed in triplicate. The P-values were assessed by the Student's t-test.

Overexpression of miR-214 and miR-218 induced early breast cancer cells apoptosis. The cells were seeded into 6-well plates and transfected with negative control, miR-214 or miR-218 mimic, and cell apoptosis were analyzed by Annexin V-FITC detection kit according to the manufacturer's protocol. Representative results of negative control (Fig. 5A), miR-214 mimic (Fig. 5B), and miR-218 mimic (Fig. 5C) are shown, respectively. The ratio of early apoptosis was analyzed by flow cytometry (Fig. 5D). The results confirmed that cell apoptosis was significantly augmented in the miR-214 or miR-218 mimic transfected cells. These results verified that miR-214 and miR-218 were able to mediate breast cancer cell apoptosis.

Overexpression of $m i R-214$ and $m i R-218$ reduced breast cancer cell migration. Cell migration was tested by wound-
A $\begin{array}{cc}\operatorname{miR}-214 & \operatorname{miR}-218 \\ \text { mimic } & \text { mimic }\end{array}$ Control mimic

$0 \mathrm{~h}$
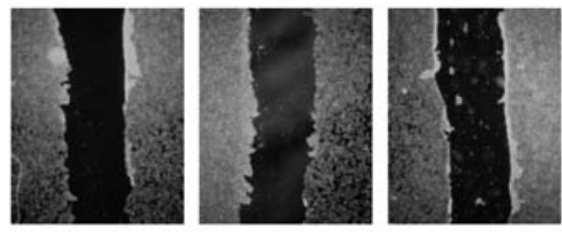

$48 \mathrm{~h}$
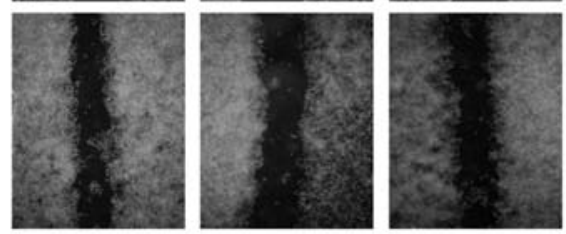

B

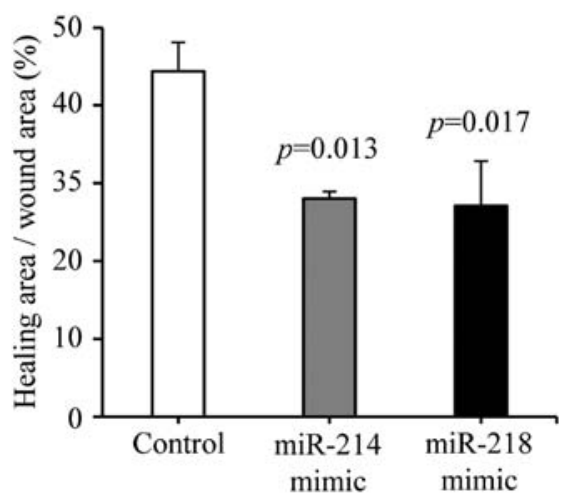

Figure 6. Effects of miR-214 and miR-218 on migration capability of breast cancer cells. After negative control, miR-214 mimic and miR-218 mimic transfection, the cell migration was measured by wound-healing assay. (A) Representative results are shown. (B) The percentage of healing area was determined using the ImageJ. The experiments were performed in triplicate. The P-values were assessed by the Student's t-test.

healing assay. Cell migration was decreased in miR-214 mimic $(28.02 \pm 0.89$ vs. $44.38 \pm 3.71 \%, \mathrm{P}=0.013)$ and $\mathrm{miR}-218$ (27.07 \pm 5.75 vs. $44.38 \pm 3.71 \%, \mathrm{P}=0.017)$ mimic treated cells compared with negative control transfected cells (Fig. 6A and $\mathrm{B})$. These results demonstrated that overexpression of miR-214 or miR-218 could inhibit breast cancer cell migration.

\section{Discussion}

The expression of miR-214 has been verified downregulated in human cervical cancer (25-27), pancreatic cancer (28), hepatocellular carcinoma $(29,30)$ and breast cancer $(28)$ and miR-218 expression is also reduced in oral squamous cell carcinoma, nasopharyngeal carcinoma, and bladder cancer cells (31-34). However, the molecular biological functions of miR-214 and miR-218 have not clarified in breast cancer. In the present study, we comprehensively evaluated the biological functions of miR-214 and miR-218 in breast cancer. The results indicated that miR-214 and miR-218 function as tumor suppressor genes in breast cancer.

In particular, expression of miR-214 and miR-218 was reduced in human breast cancer tissues, and miR-214 or miR-218 expression is negatively associated with $\mathrm{Ki}-67$, a cellular marker of tumor cells proliferation (Fig. 2). In vitro, we also validated that miR-214 and miR-218 negatively mediated MCF-7 cell proliferation and interfered with cell cycle 
(Figs. 3 and 4). Previous studies have already demonstrated that the miR-214 could suppress oncogenesis of bladder cancer by targeting the p53 and DNA damage-regulated protein 1 (PDRG1) (35), inhibit the progression of hepatocellular carcinoma by regulating $\beta$-catenin $(36,37)$, also mediating cell proliferation by targeting ERK (38), mitochondrial transcription factor A (TFAM) (39) and ADP-ribosylation factor-like protein 2 (ARL2) (40). The miR-218 suppresses lung cancer and cardiac myxoma cell growth by reducing myocyte enhancer factor 2D (MEF2D) $(41,42)$, inhibits glioma cells proliferation by inactivation of cyclin D1 (43) pathway and directly target E2F2 (24), reduces bladder cancer and esophageal squamous cells proliferation by targeting BMI-1 $(34,44)$. The above evidence supports our conclusion.

Our results also prove that the miR-214 and miR-218 promote early apoptosis of breast cancer cells (Fig. 5). The effects of miR-214 are inconsistent, but some studies above confirm that overexpression of miR-214 can promote apoptosis and the sensitivity of cisplatin $(45,46)$. In addition, miR-218 promoted prostate cancer cells apoptosis by repression tumor protein D52 (22), enhanced chemotherapy sensitivity by targeting BIRC5 and breast cancer $1(47,48)$, sensitized glioma cells to apoptosis by regulating NF- $\kappa \mathrm{B}$ (49). Our results, and the previous results imply that miR-214 and miR-218 could protect against tumorigenesis by inducing apoptosis.

The effects of miR-214 and miR-218 on breast cancer cell migration are shown in Fig. 6. Some previous research supports our results, there is evidence to prove that miR-214 could directly bind to the 3'-UTR of vascular endothelial growth factor (VEGF) (50), the 3'-UTR of polypeptide GalNAc transferase 7 (26) and the 3'-UTR of PTEN (51). The miR-218 also suppresses the cancer cell migration or invasion by downregulating high mobility group box 1, LIM and SH3 protein 1, T-cell lymphoma invasion and metastasis 1 (TIAM1), matrix metalloproteinase 2 and 9 (52-54). These genes induced cell migration or invasion. Other targets of miR-214 and miR-218 will be analyzed in the following study. Interestingly, the expression of miR-214 and miR-218 are positively associated with PR (55), although there is no statistic difference between miR-214 and PR expression. Many investigators consider that PR promotes cell migration, but some investigators still assert that progesterone or PR could exert cell migration inhibitory action (56-59). Our results suggest that PR may, via mediating miR-214 or miR-218, inhibit breast cancer migration.

In conclusion, our results show that miR-214 and miR-218 expression are decreased in breast cancer tissues. Overexpression of miR-214 or miR-218 could suppress cell proliferation and migration, disturb the cell cycle and induce cell apoptosis in vitro. Our findings suggest that miR-214 and miR-218, as tumor suppressors, could play important roles in development of breast cancer, and may be potential therapeutic targets for breast cancer. Therefore, further research on miR-214 and miR-218 functional mechanisms in breast cancer is required.

\section{Acknowledgements}

The present study was supported by the Science and Technology Support Project of Hebei, China (no. 14277755D).

\section{References}

1. Siegel RL, Miller KD and Jemal A: Cancer statistics, 2015. CA Cancer J Clin 65: 5-29, 2015.

2. Fentiman IS, Fourquet A and Hortobagyi GN: Male breast cancer. Lancet 367: 595-604, 2006.

3. Kroemer G, Senovilla L, Galluzzi L, André F and Zitvogel L: Natural and therapy-induced immunosurveillance in breast cancer. Nat Med 21: 1128-1138, 2015.

4. Spanheimer PM, Carr JC, Thomas A, Sugg SL, Scott-Conner CE, Liao J and Weigel RJ: The response to neoadjuvant chemotherapy predicts clinical outcome and increases breast conservation in advanced breast cancer. Am J Surg 206: 2-7, 2013.

5. Guo H, Ingolia NT, Weissman JS and Bartel DP: Mammalian microRNAs predominantly act to decrease target mRNA levels. Nature 466: 835-840, 2010.

6. Lim LP, Lau NC, Garrett-Engele P, Grimson A, Schelter JM, Castle J, Bartel DP, Linsley PS and Johnson JM: Microarray analysis shows that some microRNAs downregulate large numbers of target mRNAs. Nature 433: 769-773, 2005.

7. Bartel DP: MicroRNAs: Genomics, biogenesis, mechanism, and function. Cell 116: 281-297, 2004.

8. Jiang X, Kanda T, Wu S, Nakamura M, Miyamura T, Nakamoto S, Banerjee $A$ and Yokosuka O: Regulation of microRNA by hepatitis B virus infection and their possible association with control of innate immunity. World J Gastroenterol 20: 7197-7206, 2014.

9. O'Day E and Lal A: MicroRNAs and their target gene networks in breast cancer. Breast Cancer Res 12: 201, 2010.

10. Sakurai M, Masuda M, Miki Y, Hirakawa H, Suzuki T and Sasano H: Correlation of miRNA expression profiling in surgical pathology materials, with Ki-67, HER2, ER and PR in breast cancer patients. Int J Biol Markers 30: e190-e199, 2015.

11. Iorio MV, Ferracin M, Liu CG, Veronese A, Spizzo R, Sabbioni S, Magri E, Pedriali M, Fabbri M, Campiglio M, et al: MicroRNA gene expression deregulation in human breast cancer. Cancer Res 65: 7065-7070, 2005.

12. Antolín S, Calvo L, Blanco-Calvo M, Santiago MP, LorenzoPatiño MJ, Haz-Conde M, Santamarina I, Figueroa A, Antón-Aparicio LM and Valladares-Ayerbes M: Circulating miR-200c and miR-141 and outcomes in patients with breast cancer. BMC Cancer 15: 297, 2015.

13. Zhou J, Tian Y, Li J, Lu B, Sun M, Zou Y, Kong R, Luo Y, Shi Y, Wang K, et al: miR-206 is down-regulated in breast cancer and inhibits cell proliferation through the up-regulation of cyclinD2. Biochem Biophys Res Commun 433: 207-212, 2013.

14. Gao Y, Zeng F, Wu JY, Li HY, Fan JJ, Mai L, Zhang J, Ma DM, Li Y and Song FZ: MiR-335 inhibits migration of breast cancer cells through targeting oncoprotein c-Met. Tumour Biol 36: 2875-2883, 2015.

15. Song L, Liu D, Wang B, He J, Zhang S, Dai Z, Ma X and Wang X: miR-494 suppresses the progression of breast cancer in vitro by targeting CXCR4 through the Wnt/ $\beta$-catenin signaling pathway. Oncol Rep 34: 525-531, 2015.

16. Xie X, Hu Y, Xu L, Fu Y, Tu J, Zhao H, Zhang S, Hong R and $\mathrm{Gu} \mathrm{X}$ : The role of miR-125b-mitochondria-caspase-3 pathway in doxorubicin resistance and therapy in human breast cancer. Tumour Biol 36: 7185-7194, 2015.

17. Liu J, Mao Q, Liu Y, Hao X, Zhang S and Zhang J: Analysis of miR-205 and miR-155 expression in the blood of breast cancer patients. Chin J Cancer Res 25: 46-54, 2013.

18. Müller V, Gade S, Steinbach B, Loibl S, von Minckwitz G, Untch M, Schwedler K, Lübbe K, Schem C, Fasching PA, et al: Changes in serum levels of miR-21, miR-210, and miR-373 in HER2-positive breast cancer patients undergoing neoadjuvant therapy: A translational research project within the Geparquinto trial. Breast Cancer Res Treat 147: 61-68, 2014.

19. Yang X, Wang X, Shen H, Deng R and Xue K: Combination of mir-21 with circulating tumor cells markers improve diagnostic specificity of metastatic breast cancer. Cell Biochem Biophys 73: 87-91, 2015.

20. Han X, Yan S, Weijie Z, Feng W, Liuxing W, Mengquan L and Qingxia F: Critical role of miR-10b in transforming growth factor- $\beta 1$-induced epithelial-mesenchymal transition in breast cancer. Cancer Gene Ther 21: 60-67, 2014.

21. Derfoul A, Juan AH, Difilippantonio MJ, Palanisamy N, Ried T and Sartorelli V: Decreased microRNA-214 levels in breast cancer cells coincides with increased cell proliferation, invasion and accumulation of the Polycomb Ezh2 methyltransferase. Carcinogenesis 32: 1607-1614, 2011. 
22. Han G, Fan M and Zhang X: microRNA-218 inhibits prostate cancer cell growth and promotes apoptosis by repressing TPD52 expression. Biochem Biophys Res Commun 456: 804-809, 2015.

23. Dong Y, Zou J, Su S, Huang H, Deng Y, Wang B and Li W: MicroRNA-218 and microRNA-520a inhibit cell proliferation by downregulating E2F2 in hepatocellular carcinoma. Mol Med Rep 12: 1016-1022, 2015.

24. Zhang Y, Han D, Wei W, Cao W, Zhang R, Dong Q, Zhang J, Wang $\mathrm{Y}$ and Liu N: MiR-218 inhibited growth and metabolism of human glioblastoma cells by directly targeting E2F2. Cell Mol Neurobiol 35: 1165-1173, 2015

25. Yang Z, Chen S, Luan X, Li Y, Liu M, Li X, Liu T and Tang H: MicroRNA-214 is aberrantly expressed in cervical cancers and inhibits the growth of HeLa cells. IUBMB Life 61: 1075-1082, 2009.

26. Peng RQ, Wan HY,Li HF, Liu M,LiX and Tang H: MicroRNA-214 suppresses growth and invasiveness of cervical cancer cells by targeting UDP-N-acetyl- $\alpha$-D-galactosamine:polypeptide $\mathrm{N}$-acetylgalactosaminyltransferase 7. J Biol Chem 287: 14301-14309, 2012.

27. Qiang R, Wang F, Shi LY, Liu M, Chen S, Wan HY, Li YX, Li X, Gao SY and Sun BC: Plexin-B1 is a target of miR-214 in cervical cancer and promotes the growth and invasion of HeLa cells. Int J Biochem Cell Biol 43: 632-641, 2011.

28. Zhang XJ, Ye H, Zeng CW, He B, Zhang $\mathrm{H}$ and Chen YQ: Dysregulation of miR-15a and miR-214 in human pancreatic cancer. J Hematol Oncol 3: 46, 2010.

29. Duan Q, Wang X, Gong W, Ni L, Chen C, He X, Chen F, Yang L, Wang P and Wang DW: ER stress negatively modulates the expression of the miR-199a/214 cluster to regulates tumor survival and progression in human hepatocellular cancer. PLoS One 7: e31518, 2012

30. Shih TC, Tien YJ, Wen CJ, Yeh TS, Yu MC, Huang CH, Lee YS, Yen TC and Hsieh SY: MicroRNA-214 downregulation contributes to tumor angiogenesis by inducing secretion of the hepatoma-derived growth factor in human hepatoma. J Hepatol 57: 584-591, 2012.

31. Uesugi A, Kozaki K, Tsuruta T, Furuta M, Morita K, Imoto I, Omura $\mathrm{K}$ and Inazawa $\mathrm{J}$ : The tumor suppressive microRNA miR-218 targets the mTOR component Rictor and inhibits AKT phosphorylation in oral cancer. Cancer Res 71: 5765$5778,2011$.

32. Alajez NM, Lenarduzzi M, Ito E, Hui AB, Shi W, Bruce J, Yue S, Huang SH, Xu W, Waldron J, et al: MiR-218 suppresses nasopharyngeal cancer progression through downregulation of survivin and the SLIT2-ROBO1 pathway. Cancer Res 71: 23812391, 2011.

33. Tatarano S, Chiyomaru T, Kawakami K, Enokida H, Yoshino H, Hidaka H, Yamasaki T, Kawahara K, Nishiyama K, Seki N, et al miR-218 on the genomic loss region of chromosome $4 \mathrm{p} 15.31$ functions as a tumor suppressor in bladder cancer. Int J Oncol 39: 13-21, 2011.

34. Cheng Y, Yang X, Deng X, Zhang X, Li P, Tao J and Lu Q: MicroRNA-218 inhibits bladder cancer cell proliferation, migration, and invasion by targeting BMI-1. Tumour Biol 36: 8015-8023, 2015.

35. Wang J, Zhang X, Wang L, Yang Y, Dong Z, Wang H, Du L and Wang C: MicroRNA-214 suppresses oncogenesis and exerts impact on prognosis by targeting PDRG1 in bladder cancer. PLoS One 10: e0118086, 2015 .

36. Zhang LL, Guo YJ, Zhao CN and Gao JY: Effects and mechanism of miR-214 on hepatocellular carcinoma. Asian Pac J Trop Med 8: 392-398, 2015

37. Wang X, Chen J, Li F, Lin Y, Zhang X, Lv Z and Jiang J: MiR-214 inhibits cell growth in hepatocellular carcinoma through suppression of $\beta$-catenin. Biochem Biophys Res Commun 428: 525-531, 2012.

38. Yamane K, Jinnin M, Etoh T, Kobayashi Y, Shimozono N, Fukushima S, Masuguchi S, Maruo K, Inoue Y, Ishihara T, et al: Down-regulation of miR-124/-214 in cutaneous squamous cell carcinoma mediates abnormal cell proliferation via the induction of ERK. J Mol Med Berl 91: 69-81, 2013.

39. Wen Z, Lei Z, Jin-An M, Xue-Zhen L, Xing-Nan Z and Xiu-Wen D: The inhibitory role of miR-214 in cervical cancer cells through directly targeting mitochondrial transcription factor A (TFAM). Eur J Gynaecol Oncol 35: 676-682, 2014.

40. Long LM, He BF, Huang GQ, Guo YH, Liu YS and Huo JR: microRNA-214 functions as a tumor suppressor in human colon cancer via the suppression of ADP-ribosylation factor-like protein 2. Oncol Lett 9: 645-650, 2015.
41. Song L, Li D, Zhao Y, Gu Y, Zhao D, Li X, Bai X, Sun Y, Zhang X, Sun H, et al: miR-218 suppressed the growth of lung carcinoma by reducing MEF2D expression. Tumour Biol: Sep 26, 2015 (Epub ahead of print).

42. Cao Q, Dong P, Wang Y, Zhang J, Shi X and Wang Y: miR-218 suppresses cardiac myxoma proliferation by targeting myocyte enhancer factor 2D. Oncol Rep 33: 2606-2612, 2015.

43. Jun GJ, Zhong GG and Ming ZS: miR-218 inhibits the proliferation of glioma U87 cells through the inactivation of the CDK6/cyclin D1/p21 Cip1/Waf1 pathway. Oncol Lett 9: 2743-2749, 2015.

44. Wang T, Chen T, Niu H, Li C, Xu C, Li Y, Huang R, Zhao J and Wu S: MicroRNA-218 inhibits the proliferation and metastasis of esophageal squamous cell carcinoma cells by targeting BMI1. Int J Mol Med 36: 93-102, 2015.

45. Heishima K, Mori T, Sakai H, Sugito N, Murakami M, Yamada N, Akao Y and Maruo K: MicroRNA-214 promotes apoptosis in canine hemangiosarcoma by targeting the COP1-p53 axis. PLoS One 10: e0137361, 2015

46. Phatak P, Byrnes KA, Mansour D, Liu L, Cao S, Li R, Rao JN, Turner DJ, Wang JY and Donahue JM: Overexpression of miR214-3p in esophageal squamous cancer cells enhances sensitivity to cisplatin by targeting survivin directly and indirectly through CUG-BP1. Oncogene: doi:10.1038/onc.2015.271 (Epub ahead of print).

47. Li PL, Zhang X, Wang LL, Du LT, Yang YM, Li J and Wang CX: MicroRNA-218 is a prognostic indicator in colorectal cancer and enhances 5-fluorouracil-induced apoptosis by targeting BIRC5. Carcinogenesis 36: 1484-1493, 2015.

48. He X, Xiao X, Dong L, Wan N, Zhou Z, Deng H and Zhang X: MiR-218 regulates cisplatin chemosensitivity in breast cancer by targeting BRCA1. Tumour Biol 36: 2065-2075, 2015.

49. Xia H, Yan Y, Hu M, Wang Y, Wang Y, Dai Y, Chen J, Di G, Chen $\mathrm{X}$ and Jiang X: MiR-218 sensitizes glioma cells to apoptosis and inhibits tumorigenicity by regulating ECOP-mediated suppression of NF- $\kappa$ B activity. Neuro Oncol 15: 413-422, 2013.

50. Jin Y, Yang CJ, Xu X, Cao JN, Feng QT and Yang J: MiR-214 regulates the pathogenesis of patients with coronary artery disease by targeting VEGF. Mol Cell Biochem 402: 111-122, 2015.

51. Yang TS, Yang XH, Wang XD, Wang YL, Zhou B and Song ZS: MiR-214 regulate gastric cancer cell proliferation, migration and invasion by targeting PTEN. Cancer Cell Int 13: 68, 2013.

52. Liu Z, Xu Y, Long J, Guo K, Ge C and Du R: microRNA-218 suppresses the proliferation, invasion and promotes apoptosis of pancreatic cancer cells by targeting HMGB1. Chin J Cancer Res 27: 247-257, 2015.

53. Nishikawa R, Goto Y, Sakamoto S, Chiyomaru T, Enokida H, Kojima S, Kinoshita T, Yamamoto N, Nakagawa M, Naya Y, et al: Tumor-suppressive microRNA-218 inhibits cancer cell migration and invasion via targeting of LASP1 in prostate cancer. Cancer Sci 105: 802-811, 2014.

54. Jin J, Cai L, Liu ZM and Zhou XS: miRNA-218 inhibits osteosarcoma cell migration and invasion by down-regulating of TIAM1, MMP2 and MMP9. Asian Pac J Cancer Prev 14: 3681-3684, 2013

55. Lee TS, Lin JJ, Huo YN and Lee WS: Progesterone inhibits endothelial cell migration through suppression of the rho activity mediated by cSrc activation. J Cell Biochem 116: 14111418,2015

56. van der Horst PH, Wang Y, Vandenput I, Kühne LC, Ewing PC, van Ijcken WF, van der Zee M, Amant F, Burger CW and Blok LJ: Progesterone inhibits epithelial-to-mesenchymal transition in endometrial cancer. PLoS One 7: e30840, 2012.

57. Bokhari AA, Lee LR, Raboteau D, Hamilton CA, Maxwell GL, Rodriguez GC and Syed V: Progesterone inhibits endometrial cancer invasiveness by inhibiting the TGF $\beta$ pathway. Cancer Prev Res (Phila) 7: 1045-1055, 2014.

58. Xie M, Zhou L, Chen X, Gainey LO, Xiao J, Nanes MS, Hou A, You S and Chen Q: Progesterone and Src family inhibitor PP1 synergistically inhibit cell migration and invasion of human basal phenotype breast cancer cells. BioMed Res Int 2015: 426429,2015

59. Yu Y, Lee JS, Xie N, Li E, Hurtado-Coll A, Fazli L, Cox M, Plymate S, Gleave M and Dong X: Prostate stromal cells express the progesterone receptor to control cancer cell mobility. PLoS One 9: e92714, 2014. 